\title{
Moving beyond the 'black box' approach to public interventions promoting research, development and innovation. The concept of behavioural additionality
}

\author{
Paulina Kubera*
}

Traditional evaluations of public policy actions focus on the input and output side of the intervention (i.e. assume the so-called 'black box' approach), whereas the experience of public intervention also affects deeper changes of the recipient companies. Thus, a third dimension of additionality has been introduced to the evaluation theory and practice - the behavioural additionality'. It takes account of the difference in behaviour of a target population owing to a public intervention. Although the idea to evaluate how public policy interventions affect behaviour of the actors of the innovation system appears to be a very compelling line of inquiry for scholars and practitioners alike, it gives rise to many practical difficulties. This paper investigates how behavioural additionality is defined and measured as well as what are the empirical findings on behavioural additionality in the literature on evaluation of public policy instruments in the field of research, development and innovation (RDI), where this term has been coined. To this end, a quantitative systematic literature review has been conducted. Thirty-eight scientific papers which explicitly acknowledge assessing behavioural additionality in reference to RDI policy instruments, and represent original research papers in which behavioural additionality is approached empirically, have been analysed revealing the current state in the field and directions for further research. Seven different conceptualisations of the term have been identified which reflect a multidimensional nature of the concept.

Keywords: behavioural additionality, evaluation, public intervention, RDI policy.

Submitted: 3.09.18 | Accepted: 10.11.18

\section{Otwieranie „czarnej skrzynki” interwencji publicznych na rzecz badań, rozwoju i innowacji. Koncepcja efektu dodatkowości behawioralnej}

Ewaluacja dziatań publicznych zwykle koncentruje się na wktadzie $i$ wynikach danej interwencji (stosuje zatem podejście „czarnej skrzynki”); tymczasem doświadczenie interwencji publicznej wptywa także na głębsze zmiany przedsiębiorców będacych jej beneficjentami. Stąd, do teorii i praktyki ewaluacyjnej wprowadzono trzeci wymiar dodatkowości interwencji publicznych - dodatkowość behawioralna (behavioural additionality). Uwzględnia ona zmiany $w$ zachowaniu grupy docelowej zachodzace pod wptywem dziatania interwencji publicznej. Chociaż sama idea odkrywania mechanizmu zmiany, tj. jak instrumenty polityki publicznej

Paulina Kubera - PhD, Poznan University of Technology, Faculty of Management Engineering, Chair of Entrepreneurship and Business Communication.

Correspondence address: Poznan University of Technology, Faculty of Management Engineering, Chair of Entrepreneurship and Business Communication, Strzelecka St. 11, 60-965 Poznań; e-mail: Paulina. Kubera@put.poznan.pl, https://orcid.org/0000-0002-6246-6952. 
wptywaja na zachowania podmiotów systemu innowacji, wydaje się bardzo interesującym obszarem dociekań dla naukowców i praktyków, stanowi ona spore wyzwanie. Niniejszy artykut ma na celu wskazanie, jak dodatkowość behawioralna jest definiowana w odniesieniu do instrumentów polityki publicznej na rzecz badań, rozwoju i innowacji (BRI), gdzie ten termin zostat ukuty, jak można ja mierzyć i co mówiq wyniki badań empirycznych $w$ tej dziedzinie. Wykorzystano do tego metodę ilościowego systematycznego przegladu literatury. Analizie poddano trzydzieści osiem opracowań naukowych, które wyraźnie deklaruja badanie dodatkowości behawioralnej instrumentów polityki publicznej na rzecz BRI i stanowia oryginalne prace badawcze, $w$ których dodatkowość behawioralna jest badana empirycznie. $W$ ten sposób ustalono stan wiedzy $w$ tej dziedzinie i kierunki dalszych badań, m.in. zidentyfikowano siedem różnych ujęć dodatkowości behawioralnej, które oddaja wielowymiarowość badanego konceptu.

Słowa kluczowe: dodatkowość behawioralna, ewaluacja, interwencja publiczna, BRI.

Nadesłany: 3.09.18 | Zaakceptowany do druku: 10.11 .18

JEL: H32, 038

\section{Introduction}

The fundamental issue in measuring the success of a policy intervention is to determine its 'additionality', which means to what extent a particular public action is encouraging activities that would otherwise not have taken place. It is about 'making a difference' - a key subject of policy evaluation and policy design. When a public intervention fails to improve a situation compared to one where companies have not been covered by the policy initiative, better use of public resources could be made. Therefore, it needs to account for the counterfactual - what would have occurred without the intervention. For instance, a positive change in the performance of a beneficiary of public support can stem from other factors, such as general macroeconomic conditions or be due to inherent characteristics of a beneficiary.

Traditional evaluations take the black box' approach' and focus on the input and output side of the intervention, i.e. how much has been invested and what has been achieved, without exploring the mechanism of change - the process in which inputs result in outputs. Yet, this is imperative for increasing the effectiveness of public interventions (Steurs, Verbeek and Lykogianni, 2009; Gök and Edler, 2012). The issue how a particular public intervention affects the behaviour of recipient companies within as well as beyond the life-time of the public initiative under scrutiny should supplement the traditional input-output approach (Gök and Edler, 2012). A truly successful public intervention should contribute to building organisational capability in the long term. As a consequence, a third dimension of additionality has been introduced to the evaluation theory and practice - the 'behavioural additionality'. It takes account of the difference in behaviour of a target population owing to a public intervention.

The aim of the article is to provide an overview of the current knowledge on behavioural additionality, how it is defined and measured as well as what are the empirical findings on behavioural additionality in the literature on evaluation of public policy instruments in the field of research, development and innovation, where this term has been coined. The added value of the research is to reveal the state in the field, reflect on the explanatory power of the concept and on this basis formulate directions for further research. To this end, a systematic literature review has been carried out, covering thirty-eight selected original research papers. Three databases have been used: Web of Science Core Collection, Scopus and Google Scholar to study scholarship on the conceptualisation of the behavioural additionality effect.

The paper is organised into five sections. Following the introduction which provides the rationale for the research, the concept of additionality is outlined to demonstrate how the concept of behavioural additionality fits within the broader research context. The traditional approach to impact evaluation, that is input/output additionality 
approach, is discussed and contrasted with behavioural additionality approach. Two subsequent sections present the literature review design and the results of the search. In the final section the existing body of literature produced by scholars is synthesized, revealing the state in the field and directions for further research.

\section{Additionality as a rationale for public intervention and its types}

'Additionality' can be characterised as net changes which are brought about over and above what would take place anyway without public intervention (a program, project or policy) (Polt and Streicher, 2005; Georghiou and Clarysse, 2006). Therefore, assessing the additionality effect requires being sensitive about two critical issues. Firstly, one must not assume that a given situation - the state of the economic, social or environmental context - would remain constant if an intervention would not have taken place at all i.e. that the baseline position (the situation at the beginning of the intervention) would remain unchanged over the intervention period. The reference case can be better (or worse) than the baseline position, even in the absence of a public intervention under evaluation (Figure 1). This refers to the problem of deadweight.

Figure 1. The additionality effect

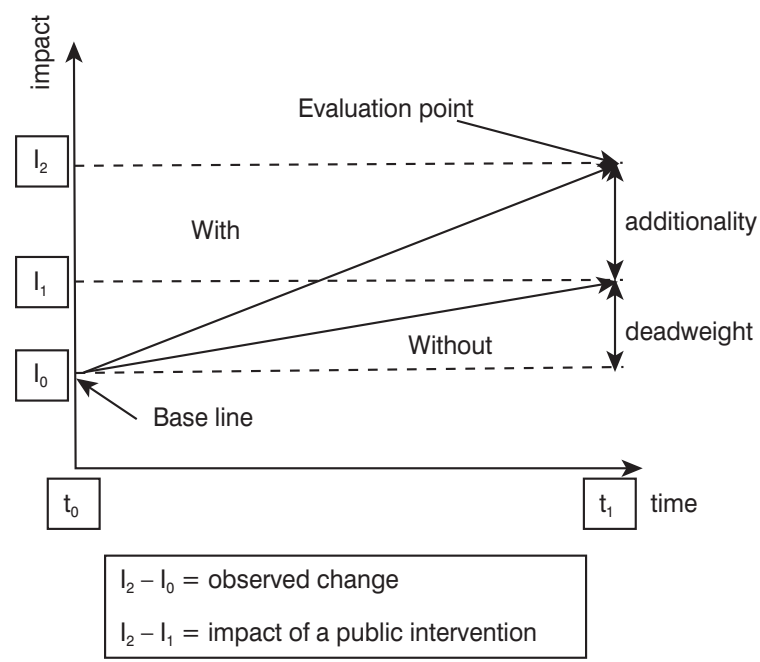

Source: based on English Partnerships (2008, p. 5).

Secondly, effects such as: displacement or substitution should also be taken into account. The reason is that sometimes effects of an intervention addressed to specific areas or groups are achieved at the expense of other areas or groups. On the other hand, benefits of an intervention can also be multiplied due to knock-on effects within the economy and leak outside the intervention target area or group (English Partnerships, 2008).

There are different types of additionality that can be distinguished. The most common division encompasses: input, output, and behavioural additionality (OECD, 2010).

Input additionality describes the extent to which intervention supplements or substitutes for inputs provided by other means - the market or recipient's own resources. For instance - whether public funding supplements or substitutes private RDI investment (the latter case is referred to as the crowding-out effect). It was a first generation of studies in the field of RDI policy - econometric evaluations which focus on the initial stage of multiplier effects of subsidies on the total amount of $\mathrm{R} \& \mathrm{D}$ expenditure (for a review see: David et al., 2000 and Gonzales and Panzo, 2008).

However, rejection of the crowding-out effect of public support (which is the most intensely studied issue within the input additionality evaluation), does not automatically translate into product or process innovations, since the linear approach to innovation process has been abandoned as insufficient to explain the complete phenomena of innovation. Thus, the output additionality identifies the proportion of what would not have been created without public intervention; in other words, due to public support a recipient achieves more, compared to the output that would result without it. This additional output can be confined to the introduction of new products or production processes or patenting activity of a beneficiary (e.g. a number of patented inventions), or be affiliated with productivity growth and such factors as growth in turnover and export, in employment, value of an enterprise, etc. Nevertheless, examining the input and output side of the innovation process still isn't sufficient for policy makers. It is argued that RDI public interventions should be judged on the basis of more than their immediate material returns or directly measurable indicators - namely, also with reference to 
intangible social returns, such as competence building or networking effects (Falk, 2006).

In order to understand the long term effects of public support for RDI, factors concerning the change in behaviour of the recipient should be taken into account. Hence, the concept of behavioural additionality has been introduced, which refers to the difference in behaviour of a target population owing to a public intervention. Initially, the focus had only been on one issue: how public interventions modify the manner in which a supported project is carried out. To this end, the analogy to opening of the black box was used (Clarysse et al., 2006, Steurs et al. 2006). Later, the focus has shifted towards more persistent changes in beneficiaries' behaviour, going beyond the lifetime of the supported initiative. Autio et al. (2008), for instance, refer to a broader range of learning results of R\&D subsidies as 'second-order additionalities', whereas to input and output additionality as 'first-order additionalities'. This form of additionality is the least examined due to practical difficulties and yet it plays a critical role in understanding the wider and more sustained impact of public interventions.

Table 1. Traditional (input/output) versus behavioural additionality approach

\begin{tabular}{|l|l|}
\hline \multicolumn{1}{|c|}{$\begin{array}{c}\text { Traditional additionality approach } \\
\text { (input/output additionality approach) }\end{array}$} & \multicolumn{1}{c|}{ Behavioural additionality approach } \\
\hline $\begin{array}{l}\text { the 'black box' type of evaluation: quantitative } \\
\text { questions: how much something has changed? } \\
\text { in which direction it changed? how much was } \\
\text { invested in a given project (input), how much } \\
\text { was achieved through its implementation } \\
\text { (output) - the focus is on a stimulus (input) } \\
\text { and a response (output) }\end{array}$ & $\begin{array}{l}\text { opening the 'black box' of public interventions } \\
\text { - qualitative questions: how have the resources } \\
\text { involved been transformed into results? why } \\
\text { has something changed? what was the change } \\
\text { mechanism? what is the pattern of the change? }\end{array}$ \\
\hline linear models & non-linear models \\
\hline $\begin{array}{l}\text { market failure as a rationale for public } \\
\text { interventions }\end{array}$ & $\begin{array}{l}\text { system deficiencies as a rationale for public } \\
\text { interventions }\end{array}$ \\
\hline $\begin{array}{l}\text { to estimate the impact is the main challenge } \\
\text { (attribution problem), the focus is on solving } \\
\text { the problems arising from counterfactual } \\
\text { analysis (e.g. finding a suitable control group); }\end{array}$ & $\begin{array}{l}\text { policy learning is the main challenge } \\
\text { (improving policy design); the problem of } \\
\text { comparative analysis (e.g. finding similar } \\
\text { situations) }\end{array}$ \\
\hline redistributive function of state & state as a catalyst \\
\hline $\begin{array}{l}\text { static approach - the comparison of situations } \\
\text { before and after some particular intervention; }\end{array}$ & $\begin{array}{l}\text { dynamic approach - interest in the process, } \\
\text { often includes more than two observations } \\
\text { and does not include the "ceteris paribus" } \\
\text { assumption }\end{array}$ \\
\hline
\end{tabular}

Source: on the basis of Larosse $(2004, p .62)$.

\section{Methods}

Although the idea to evaluate how public policy interventions affect behaviour of the actors of the innovation system appears to be a very compelling line of inquiry for scholars and practitioners alike, it still gives rise to many practical difficulties. Hence, in order to determine the state of the art on the conceptualisation of the behavioural additionality effect, how the problem is approached, a 'quantitative systematic literature' review has been conducted, using the method outline by Pickering and Byrne (2014) which is deemed useful for assessing emerging trends within disciplines. The review is systematic, as the methods used to survey the literature and select papers are explicit and reproducible. It is quantitative, as it quantifies where there is research as well as where there are gaps. Each publication under review is classified into categories adopted by 
a researcher according to his or her areas of interest (e.g. subject, a unit of analysis, timeframes, methods used etc.). It also enables to highlight the boundaries around generalisations emerging from the literature (Pickering and Byrne, 2014).

This review involves searching the literature using three online databases: Web of Science Core Collection, Scopus and GoogleScholar, to find all relevant papers that fit specific criteria. Searching for 'behavioural/behavioral additionality', 'behavioural incrementality' (in Canadian terminology) as well as 'second-order addi- tionality,' 'indirect additionality' and 'process additionality', covering title, abstract and key word section, fifty-six scientific journal articles, book chapters, and other research papers have been identified. ${ }^{1}$ Thirty-eight of them have been selected for a literature review on the basis of the following inclusion criteria: (1) they explicitly acknowledged assessing behavioural additionality, (2) in reference to public policy measures fostering RDI and (3) they represent an original research papers, in which behavioural additionality is approached empirically. ${ }^{2}$

Table 2. Types of publications under review

\begin{tabular}{|l|l|l|}
\hline \multicolumn{1}{|c|}{ scientific journal articles } & \multicolumn{1}{|c|}{ book chapters } & \multicolumn{1}{c|}{ other research papers } \\
\hline $\begin{array}{l}(1),(2),(17),(18),(19),(20), \\
(22),(24),(26),(27),(28),\end{array}$ & $(3),(4),(5),(6),(7),(8),(10)$, & \\
$(31),(32),(33)(36),(37),(38)$ & $(21),(25),(29),(30),(15)$, & $(9),(16),(23),(34),(35)$, \\
\hline \multicolumn{1}{|c|}{ Total number: 17 } & \multicolumn{1}{|c|}{$\mathbf{1 6}$} & $\mathbf{5}$ \\
\hline
\end{tabular}

(1) Davenport, Grimes and Davies (1998); (2) Polt and Streicher (2005); (3) Department of Industry, Tourism and Resources of Australia (2006); (4) Falk (2006); (5) Steyer, 2006; (6) Clarysse, Bilsen and Steurs (2006); (7) Hyvärinen (2006); (8) Fier, Aschhof and Löhlein (2006a), (9) Aschhoff, Fier and Löhlein (2006), (10) Suzuki and Yumitori (2006); (11) Shin (2006); (12) Madsen and Brastad (2006); (13) Malik, Georghiou and Cameron (2006); (14) Shipp, Wisniewski, Wang and Campbell (2006); (15) Polt and Psarra (2006); (16) Falk (2004); (17) Autio, Gustaffson and Kanninen (2008); (18) Hall and Maffioli (2008); (19) Hsu, Horng and Hsueh (2009); (20) Breschi, Cassi, Malerba and Vonortas (2009); (21) Steurs, Verbeek and Lykogianni (2009); (22) Clarysse, Wright and Mustar (2009); (23) Gök (2010); (24) Chávez (2011); (25) Larrea, Aranguren and Karlsen (2012); (26) Meuleman and De Maeseneire (2012); (27) Teirlinck and Spithoven (2012); (28) Wanzenboeck, Scherngell and Fischer (2013); (29) Prota, D’Eposito, De Stefano, Giordano and Vitale (2013); (30) Prota, and Vitale (2014); (31) Marzucchi, Antonioli and Montresor (2015); (32) Neicu, Teirlinck and Kelchtermans (2016); (33) Cerulli, Gabriele and Potì (2016); (34) Roper and Hewitt-Dundas (2016); (35) Pérez (2016); (36) Hulsink and Scholten, (2017); (37) Wu (2017); (38) Chapman and Hewitt-Dundas (2018).

Source: own elaboration.

\section{Results}

\subsection{How behavioural additionality is defined?}

In general terms, behavioural additionality is defined as the difference in a company's behaviour resulting from a public intervention (e.g. as a result of using a subsidy for $R \& D$ project). And here the consensus among researchers regarding the definition of behavioural additionality effect ends. There is a vast array of different theoretical approaches to this problem. The most prominent distinction is found in the timeframe taken into account while assessing the behavioural additionality. Some authors focus entirely on behavioural changes during a public intervention, as a rule - an implementation of the subsidised project, placing behavioural additionality inbetween input and output of a public policy measure. Alternatively, others emphasise long term behavioural impacts of public interventions. They not only ask a question how RDI policy instruments change the way in which a subsidised project is carried out, but also how this can be done in a more persistent way, moving beyond the impulse of the initial intervention (Georghiou and Laredo, 2006).

The first category, which I call 'oneoff company-level additionality effects' 
encompasses behavioural changes occurring during a public intervention. This line of inquiry can be labelled as being consistent and can be neatly broken into three subcategories:

- project additionality - the availability of public aid influences the decision to launch a project or undertake other RDI activities, that would not be carried out in the absence of public intervention;

- scope and scale additionality - a public intervention enables the expansion of scope and scale of a supported project or other RDI activities;

- acceleration additionality - a public intervention influences the pace of the project implementation by enabling a beneficiary to complete a particular project or other RDI activities over a shorter period of time.

The second category, which I call "persistent company-level additionality effects", is much more diverse. In this approach behavioural additionality is defined as 'the persistent change in what the target group of the policy is doing and how they are doing it, whereby this change is attributable to the policy action" (Gök and Edler, 2012 , p. 2). What tells this category apart from the first one - is persistency, effects of an intervention are sustained over time, strengthening a policy's latent ability to influence the creation of output additionality beyond the frames of the project supported or public aid offered (e.g. Davenport et al., 1998). Some of these definitions overlap each other. However, as they highlight different aspects of behavioural changes, I have broken this category into three subcategories:

- strategic additionality - a public intervention induces changes in the company's strategic management of R\&D and innovation (e.g. Davenport et al. (1998) identify the changes in managers' attitudes towards R\&D after involvement in a supported collaborative $R \& D$ programme and determine subsequent $R \& D$ place in the overall operating structure of the organisation; in the similar vein - Chapman and Hewitt-Dundas (2018) examine how innovation vouchers influence senior managers innovation-oriented attitudes; Department of Industry, Tourism and Resources of Australia (2006) defines behavioural additionality in terms of the increased commitment to $R \& D$ and understanding of the benefits of $\mathrm{R} \& \mathrm{D}$, what in turn encourages the supported companies to apply for other forms of government assistance; Steyer (2006) finds out that public support induces companies to carry out more technologically risky and complex projects and pursue more challenging aims; Malik et al. (2006) raise the question whether public support helps to overcome a loc$\mathrm{k}$-in failure by introducing a company to a new or extended technology or market area);

- disciplinary effects (operational additionality) - a public intervention induces changes in the way the recipient companies operationally manage the $R \& D$ and innovation related activities - are manifested through greater management rigour; might be enforced in the application and reporting requirements, which are then institutionalised into the company's further activities; (e.g. Department of Industry, Tourism and Resources of Australia (2006) investigates generation of and/or entrenched change in project management; Steyer et al. (2009) investigate whether companies develop improved R\&D management capabilities while carrying out publicly funded $\mathrm{R} \& \mathrm{D}$ projects).

- changes in the pattern of collaboration - a public intervention induces a persistent change in the pattern of collaboration of a target population (e.g. Department of Industry, Tourism and Resources of Australia (2006) considers a formation of new collaboration with companies which is expected to continue; Steyer (2006) reports an increase of companies' investment into external R\&D and the change in the companies' attitude towards the science-industry sector; Breshi et al. (2009) write about 'linkage additionality' to describe effects of the public programmes supporting $\mathrm{R} \& \mathrm{D}$, what denotes strengthening overall network connectivity through public support).

Actually, one more dimension of behavioural additionality explored in the literature should be distinguished - system level effects, as public interventions can induce behavioural changes also in other actors of the innovation system. This category takes 
account of a learning - enhancing externality beyond the direct beneficiaries of a public intervention, e.g. knowledge-spillovers, improved coordination (e.g. Autio et. al, 2008), or positive impact on the company image/credibility (referred to as the signal/certification effect, e.g. Clarysse et al., 2006; Hyvärinen, 2006; Hulsink and Scholten, 2017; Wu, 2017).

Usually, one study concerns more than one dimension of behavioural additionality. Table 3 shows that the largest number of publications use collaboration as an indicator of behavioural change.

Table 3. Theoretical approaches to behavioural additionality

\begin{tabular}{|c|c|c|}
\hline \multicolumn{2}{|r|}{$\begin{array}{c}\text { Dimensions of behavioural additionality } \\
\text { - publications in total }\end{array}$} & Publications \\
\hline \multirow{3}{*}{ 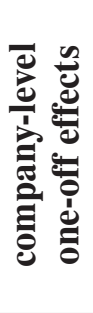 } & project additionality -9 & $\begin{array}{l}(3),(4),(5),(7),(12),(13),(16),(21), \\
(28)\end{array}$ \\
\hline & scale \& scope additionality -14 & $\begin{array}{l}(2),(3),(4),(5),(6),(8),(9),(12),(15), \\
(16),(19),(21),(28),(32)\end{array}$ \\
\hline & acceleration additionality -14 & $\begin{array}{l}(2),(3),(4),(5),(6),(8),(9),(12),(15), \\
(16),(19),(21),(32),(36)\end{array}$ \\
\hline \multirow{3}{*}{ 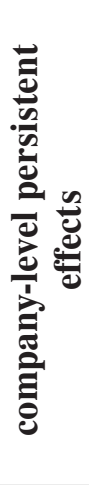 } & strategic additionality -18 & $\begin{array}{l}(1),(3),(5),(6),(7),(10),(11),(12), \\
(13),(14),(18),(19),(21),(23),(32), \\
(35),(36),(38)\end{array}$ \\
\hline & changes in the pattern of collaboration -25 & $\begin{array}{l}(1),(3),(5),(6),(7),(8),(9),(10),(12), \\
(13),(14),(19),(20),(21),(22),(23), \\
(24),(27),(28),(29),(30),(31),(33), \\
(34),(35)\end{array}$ \\
\hline & $\begin{array}{l}\text { disciplinary effects }-17 \\
\text { (operational additionality) }\end{array}$ & $\begin{array}{l}(1),(3),(5),(6),(7),(8),(9),(10),(12), \\
(13),(14),(19),(21),(22),(23),(34), \\
(36),\end{array}$ \\
\hline 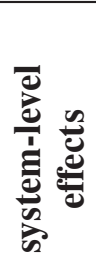 & 11 & $\begin{array}{l}(5),(6),(7),(10),(13),(17),(19),(25), \\
(26) ;(36),(37)\end{array}$ \\
\hline
\end{tabular}

Source: own elaboration.

\subsection{How behavioural additionality is measured? Which research designs and methods are used?}

One of the most challenging tasks in estimating additionality of public interventions consists in constructing the counterfactual situation - what would have happened if no intervention had taken place; and in reference to behavioural additionality - how the recipient company would have behaved should it had not been covered by a public policy measure. There are three basic research designs to address the problem of causality (attribution): experi- mental, quasi-experimental and non-experimental design.

The experimental design is often labelled as the 'golden standard' in establishing cause-and-effect inferences. It employs random assignment to groups, which are compared (so-called treatment group - companies to which a policy instrument is addressed and to a control group - companies not exposed to this policy intervention) as the main attribution mechanism to explain the differences caused by public interventions; then there is no systematic difference between the groups. However, 
a randomised assignment to a treatment group is in practice very problematic in view of the values and assumptions underpinning public policy interventions. In the literature under review, none of the researchers employ an experimental design to detect behavioural additionality.

Instead, they rely on quasi-experimental design and non-experimental design. In the first case they mainly use such methods as: propensity score matching and regression discontinuity design, which take account of the selection bias problem. It arises when participants of a specific programme (intervention) are systematically different than non-participants even before they receive public support. There are two main types of selection bias: self-selection and committee-selection (agency selection). The former occurs when companies voluntarily decide whether to apply for aid or not. In the case of aid schemes for innovative projects, companies that are more growthoriented are more likely to become beneficiaries of such programmes. In the same vein, owing to their motivation and dynamism they are also more likely to perform better even without public assistance compared to those who lack ambition and cre- ativity. The committee selection, instead, occurs in the case of aid schemes where only a portion of potential beneficiaries are awarded public support. It is argued that public authorities may follow a 'pickingthe winner' strategy - for instance, companies which are more engaged in RDI activity in the first place are also more likely to receive more aid for RDI (Aerts and Czarnitzki, 2006, p. 12). The tricky task here is to find a control group as similar as possible to the treatment group (covered by a public intervention) to make a sound comparison. The composition of a reliable control group was not always feasible. Polt and Streicher (2005), for instance, in order to confirm the high additionality found among beneficiaries did a cross-check in a parallel survey of a sample of rejected applicants. Falk also compares responses of successful applicants with failed applicants. The first group was asked hypothetical questions about what would have happened if they had not received funding, the latter - about what actually happened to their proposed projects. Steyer (2006), rather than a control group approach used the before-and-after comparison and on the top of it applied the data from the

Table 4. Research design and methods used to assess behavioural additionality

\begin{tabular}{|c|c|c|}
\hline \multicolumn{2}{|c|}{ Methods for measuring behavioural additionality } & \multirow[t]{2}{*}{ Publications: } \\
\hline 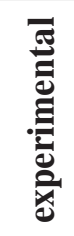 & randomised experiments -0 & \\
\hline \multirow{3}{*}{ 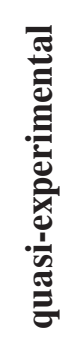 } & regression discontinuity design -5 & (2), (4), (15), (16), (26) \\
\hline & propensity score matching -6 & (8), (9), (18), (22), (24), (32) \\
\hline & other -6 & $(11),(27),(28),(33),(34),(37)$ \\
\hline \multirow{4}{*}{ 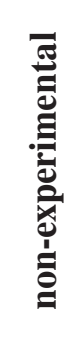 } & interviews -6 & $(1),(3),(6),(10),(12),(21)$ \\
\hline & survey -6 & (5), (7); (10); (14); (17); (19) \\
\hline & case studies -5 & $(13),(23),(25),(35),(36)$ \\
\hline & social network analysis -3 & $(20),(29),(30)$ \\
\hline
\end{tabular}

Source: own elaboration. 
Community Innovation Survey to validate the findings. Chavez (2011), in turn, apart from using the matching technique (propensity score matching and the nearest neighbour matching algorithm) to tackle the endogeneity and self-selection problems, employed a structural equation model to have an explanatory model of the mechanisms working behind the subsidy.

Finally, the non-experimental design, the most heterogeneous of these three types, is reckoned the weakest in terms of making casual statements. Commonly, studies which fall within this group are purely observational and the results are descriptive. Variables are not deliberately manipulated nor is the setting controlled. A researcher observes the phenomena as they occur, very frequently ex post. The methods are: opinion surveys, interviews, and more in-depth case-studies.

Table 4 shows that methods most frequently used for measuring behavioural additionality are: surveys and interviews, which include the perceived counterfactual scenario or directly inquiring about the impact of the intervention. The respondents were chosen among senior executives and project administrators as they are deemed to be best-positioned to make an assessment. Equally popular are matching techniques, in particular propensity score matching. Rare but very promising seems social network analysis as a tool to evaluate behavioural additionality. Breschi et al. (2009, p. 851) concludes: "The most important outcome of the study is the confirmation that social network analysis is an empirical tool amenable to application in appraising the effectiveness of publicly funded RTD programmes. It is especially well suited to answer questions of 'behavioural additionality' that hitherto been addressed only qualitatively."

\subsection{What are the empirical findings on behavioural additionality?}

An overwhelming majority of studies on behavioural additionality report positive effects (28 out of 38 ). It means that a public intervention under investigation induces behavioural changes of target population in the desired direction. Only few provide evidence of no additionality (2 papers) or mixed results ( 8 papers). What is striking is that none of the publications under review reports negative additionality.
The worst of the possible scenarios i.e. that the intervention has led to perverse effects, although signalled in the literature, is not thoroughly investigated (see e.g. Polt and Psarra, 2006; Clarysse, Wright and Mustar, 2009). This constitutes a research gap in the existing literature. Taking into account how the concept of behavioural additionality is captured in questionnaires, such an option sometimes simply does not come into question and the most extreme case is no impact observed (no additionality), (see e.g. Steyer, 2006, p. 84; Steurs, Verbeek and Lykogianni, 2009, p. 159). Moreover, it is debatable whether such effects as: increased risk tolerance, entering into new market, new collaboration, should always be deemed as manifestations of positive behavioural additionality. In my opinion, these require a deeper analysis. Fier, Aschof and Löhlein (2006a), for instance, find out that newly established R\&D co-operations with science, compared to already existing co-operations, are less likely to be continued after the funding has ended. When persistency is an element of the behavioural additionality definition, one cannot talk about positive effects of a public intervention. Moreover, the research carried out by Clarysse, Wright and Mustar (2009) shows that learning effects decrease with the number of subsidised projects. The highest impact on behavioural additionality takes place in the first subsidised project when the companies, in fact, optimise their management processes. However, the companies which are frequent 'customers' of a subsidising agency and have high level of R\&D intensity, claim that interaction with an agency has even negative additionality and inhibit their processes.

What, instead, should be perceived as the right direction in evaluation of behavioural additionality is segmenting the recipient companies according to their size and R\&D intensity as one can expect in these cases different behavioural changes induced by a public intervention. Large companies with a formalised innovation decision-making process rarely condition their decision whether to launch a given project upon receiving public support nor fundamentally adapt their strategy or management processes to make project fundable from public resources (see e.g. Clarysse, Bilsen and Steurs, 2006; Sters, Verbeek and Lykogianni, 2009). 


\begin{tabular}{|l|l|l|l|}
\hline \multicolumn{1}{|c|}{ Positive } & \multicolumn{1}{|c|}{ no additionality } & Negative & \multicolumn{1}{c|}{ mixed results } \\
\hline$(1),(2),(3),(4),(5),(6)$, & $(8),(9)$ & & $(21),(22),(23),(25)$, \\
$(7),(10),(11),(12),(13)$, & & & \\
$(14),(15),(16),(17),(18),(28),(34),(35)$ & & \\
$(19),(20),(24),(26),(29)$, & & & \\
$(30),(31),(32),(33),(36)$, & & & \\
$(37),(38)$ & & 0 & 8 \\
\hline total: 28 & 2 & & \\
\hline
\end{tabular}

Source: own elaboration.

\section{Conclusions and discussion}

The literature shows that behavioural additionality is a multidimensional concept. At least seven definitions of behavioural additionality can be identified in the literature under review. First three can be put under the common heading: 'one-off company-level effects', as they capture only those changes which occur during a public intervention, most frequently - during the implementation of a subsidised project; and these are: project additionality, scale \& scope additionality and acceleration additionality. It is worth mentioning that while some authors investigate these issues, they do not treat them as a manifestation of behavioural additionality, but as an extension of input additionality (e.g. Davenport et al., 1998). Moreover, these conceptualisations of behavioural additionality are consistent with the concept of 'incentive effect' under State aid rules (see: Communication from the Commission Framework for State aid for research and development and innovation 2014/C 198/01 par.4.4). Thus, the postulate is to link these two lines of inquiry - ex ante State aid control of aid measures with their ex-post impact evaluation more closely to verify whether the assumptions underpinning the aid granted are valid.

Other conceptualisations of behavioural additionality emphasise the sustainability of the changes observed. In this case three sub-categories have been put forward. First, it is strategic additionality - assumed to be the most durable and desirable impact of public interventions; this reflects an increased commitment of a company to $\mathrm{R} \& \mathrm{D}$ and innovation, encompasses situations where public intervention stimulates companies to enter into a new enabling technology, to undertake research beyond the company's short term business trends, more risky research or to integrate $R \& D$ and innovation strategy into their business strategy. Second - encompasses disciplinary effects, that is the changes in the way the recipient companies operationally manage the $\mathrm{R} \& \mathrm{D}$ and innovation related activities, and is essentially manifested through greater management rigour. This is where the differences between the most frequently used innovation policy measures: subsidies and tax incentives, are clearly visible. Whereas subsidies are typically awarded on the basis of the quality of a proposal, technical ability of a company and potential market, tax incentives usually require less administrative burden. As a consequence, it can be assumed that direct public support will lead to higher disciplinary effect on the part of an applicant company. However, further research about which are the behavioural mechanisms induced by different types of policy measures or what can be even more interesting for policy makers - which are the combined effects upon companies which benefit from more public interventions (the so called 'policy mix') is needed. A rare example is a study by Neiu et al. (2016). The third sub-category includes changes in the pattern of collaboration, which is a very common approach to the issue. Cunningham and Gök (2016, p. 253) argue that: 'The majority of evaluations and scholarly studies discussing the concept of behavioural additionality use collaboration as one of the key, if not the sole behaviours on which they focused.' However, only a fraction of them addresses the problem of the continuity of cooperation (e.g. Fier, Aschhof and Löhlein, 2006) or the costs of cooperation (e.g. Cerulli et al., 2016). Finally, public interventions can lead 
not only to the behavioural changes of the companies to which they were directly addressed but can also encourage behavioural changes of other innovation system's actors (e.g. knowledge-spillovers, improved company credibility). These behavioural additionalities have been labelled 'systemlevel additionality'.

Against this vast array of different conceptualisations of behavioural additionality, one can wonder whether a single definition is in fact needed for the concept to have full explanatory power. I think that sorting out - introducing sub-categories of behavioural additionality (what this article is striving for) is more practical and better corresponds to various policy needs. However, the way behavioural additionality is defined influences the research design and methods applied to its measurement. In the literature under review behavioural additionality is captured using quasi-experimental design (regression discontinuity design and propensity score matching in particular), as well as non-experimental design (and more qualitative approaches: opinion surveys, interviews, case-studies, etc.). In the first case, these methods are deemed more reliable for establishing cause-and-effect inferences. However, at the same time it can be argued that they follow the same black-box analogy as the input-output approach. They, for instance, track how many new collaborations have been established due to a public intervention, with whom etc. but without exploring why these effects occurred at all. Case studies and qualitative approaches seem better suited for this purpose. However, there is a threat to validity of the generalisability of the causal relationship between the cause and effect in a particular setting. Thus, it seems reasonable to combine different methods of measuring behavioural additionality.

The final observation is that the literature under review in vast majority reports positive behavioural additionality. This is in line with the view of Cunningham, Gök and Larèdo (2016, p. 83), as they conclude: 'It is very difficult to reach a conclusion from the analysis of the behavioural additionality studies. Unlike impact additionality and output additionality studies, behavioural additionality studies always report positive results...' Nevertheless, one cannot deny perverse effects of public intervention, e.g. when a public intervention induces companies to take risks they cannot afford, where it leads to wrong direction of technology or the market, or to enter into alliances which prove unproductive and costly. Yet, the problem of negative additionality seems to be only signalled in the literature on the evaluation of behavioural additionality and deserves further investigation; inter alia, costs and administrative burdens associated with a public support should be more properly taken into account.

\section{Endnotes}

1 It is worth mentioning that behavioural additionality is the term coined precisely in the context of innovation policy; Scolar Search: TITLE-ABS-KEY ("behavioural additionality" OR "behavioral additionality" OR "behavioural incrementality" OR "second-order additionality" OR "indirect additionality" OR "process additionality"); GoogleScholar Advanced Search: find articles with at least one of the word in the title of the articles: ("behavioural additionality" OR "behavioral additionality" OR "behavioural incrementality" OR "secondorder additionality" OR "indirect additionality" OR "process additionality") / without patents and citations; Web of Science Core Collection Search: TOPIC: ("behavioural additionality" OR "behavioral additionality" OR "behavioural incrementality" OR "second-order additionality" OR “indirect additionality" OR "process additionality"), Timespan: All years. Indexes: SCI-EXPANDED，SSCI，A\&HCI，CPCI-S, CPCI-SSH, BKCI-S, BKCI-SSH, ESCI, CCREXPANDED, IC.

2 Fifteen publications have been rejected on the grounds of not fulfilling the inclusion criteria (their nature being mainly theoretical).

\section{References}

Aschhoff, B., Fier, A. and Löhlein, H. (2006). Detecting Behavioural Additionality. An Empirical Study on the Impact of Public R\&D Funding on Firms' Cooperative Behaviour in Germany. ZEW Discussion Paper 06-037.

Autio, E., Gustaffson, R. and Kanninen, S. (2008). First- and second-order additionality and learning outcomes in collaborative R\&D programs. Research Policy, 37, 59-76.

Breschi, S., Cassi, L., Malerba, F. and Vonortas, N. (2009). Networked research: European policy intervention in ICTs. Technology Analysis and Strategic Management, 21(7), 833-857.

Cerulli, G., Gabriele, R. and Potì, B. (2016). The role of firm $\mathrm{R} \& \mathrm{D}$ effort and collaboration as medi- 
ating drivers of innovation policy effectiveness. Industry and Innovation, 23(5), 426-447.

Chapman, G. and Hewitt-Dundas, N. (2018). The effect of public support on senior manager attitudes to innovation. Technovation, 69, 28-39.

Chávez S. (2011). Behavioural additionality in the context of regional innovation policy in Spain. Innovation Organization \& Management, 13(1), 95-110.

Clarysse B., Bilsen, V. and Steurs, G. (2006). Behavioural Additionality of the R\&D Subsidies Programme of IWT-Flanders (Belgium). In: OECD (ed.). Government $R \& D$ Funding and Company Behaviour: Measuring Behavioural Additionality (pp. 91-114). OECD Publishing.

Clarysse, B., Wright, M. and Mustar, P. (2009). Behavioural additionality of R\&D subsidies: A learning perspective. Research Policy, 38(10), 1517-1533.

Cunningham P. and Gök, A. (2016). A The Impact of Innovation Policy Schemes for Collaboration. In: J. Edler, P. Cunningham, A. Gök and P. Shapira (eds.), Handbook of Innovation Policy Impact. (pp. 239-278). Edward Elgar Publishing.

Cunningham, P., Gök, A. and Larédo, P. (2016). The Impact of Direct Support to R\&D and Innovation in Firms. In: J. Edler, P. Cunningham, A. Gök and P. Shapira (eds.), Handbook of Innovation Policy Impact. (pp. 54-107). Edward Elgar Publishing.

Davenport, S., Grimes, C. and Davies, J (1998). Research collaboration and behavioural additionality: A New Zealand case study. Technology Analysis \& Strategic Management, 10, 55-67.

David P., Hall, B. and Toole, A. (2000). Is public R\&D a complement or a substitute for private R\&D? Research Policy, 29, 497-529.

Department of Industry, Tourism and Resources of Australia (2006). Behavioural Additionality of Business R\&D Grant Programmes in Australia, In: OECD (Ed.) Government R\&D Funding and Company Behaviour: Measuring Behavioural Additionality (pp. 39-58). OECD Publishing.

English Partnerships (2008). Additionality Guide, A Standard Approach to Assessing the Additional Impacts of Interventions. Third Edition, September. London: English Partnerships.

Falk, R. (2004). Behavioural Additionality Effects of $R \& D$ Subsidies: Empirical Evidence from Austria. Austrian Institute of Economic Research (WIFO). http://citeseerx.ist.psu.edu/viewdoc/download?doi= 10.1.1.535.9539\&rep = rep1\& type $=$ pdf

Falk, R. (2006). Behavioural additionality of Austria's Industrial Research Promotion Fund (FFF). In: OECD (ed.). Government R\&D Funding and Company Behaviour: Measuring Behavioural Additionality (pp. 59-74).OECD Publishing.
Fier A., Aschhof, B. \& Löhlein, H. (2006a). Behavioural Additionality of Public R\&D Funding in Germany. In: OECD (ed.), Government R\&D Funding and Company Behaviour: Measuring Behavioural Additionality (pp. 127-150). OECD Publishing.

Gök, A. (2010). An Evolutionary Approach to Innovation Policy Evaluation: Behavioural Additionality and Organisational Routines. Manchester: PREST, The University of Manchester.

Gonzales X. and Pazo, C. (2008). Do public subsidies stimulate private R\&D spending? Research Policy, 37, 271-389.

Gök, A. and Edler, J. (2012). The use of behavioural additionality evaluation in innovation policy making. Research Evaluation, 21, 306-318.

Hall, B. and Maffioli, A.(2008). Evaluating the impact of technology development funds in emerging economies: Evidence from Latin America. European. Journal of Development Research, 20(2), 172-198.

Hsu, F.-M., Horng, D.-J. and Hsueh, C.-C. (2009). The effect of government-sponsored R\&D programmes on additionality in recipient firms in Taiwan. Technovation, 29(3), 204-217.

Hulsink, W. and Scholten, V. (2017). Dedicated funding for leasing and sharing research and test facilities and its impact on innovation, follow-on financing and growth of biotech start-ups: the Mibiton case. Venture Capital, 19(1-2), 95-118.

Hyvärinen, J. (2006). Behavioural Additionality of Public R\&D Funding in Finland. In: OECD (ed.), Government R\&D Funding and Company Behaviour: Measuring Behavioural Additionality (pp. 115-126). OECD Publishing.

Larosse, J. (2004). Conceptual and empirical challenges of evaluating the effectiveness of innovation policies with 'behavioural additionality' (the case of IWT R\&D subsidies). In: L. Georghiou, B. Clarysse, G. Steurs, V. Bilsen and J. Larosse (eds.), 'Making the Difference'. The Evaluation of 'behavioural additionality' of $R \& D$ subsidies. IWTObservatory, 48, 57-69.

Larrea, M., Aranguren, M. and Karlsen, J. (2012). New policy approaches to develop innovative territories: Developing trust and behavioral additionality in Gipuzkoa. In: P. Cooke, M. Parrilli and J. Curbelo (eds.), Innovation, Global Change and Territorial Resilience (pp. 150-165). Edward Elgar.

Madsen, E. and Brastad, B. (2006). Behavioural Additionality of Innovation Norway's Financial Support Programmes. In: OECD (ed.), Government $R \& D$ Funding and Company Behaviour: Measuring Behavioural Additionality (pp. 181-204). OECD Publishing.

Malik, K., Georghiou, L. and Cameron, H. (2006). Behavioural Additionality of the UK SMART and LINK Schemes. In: OECD (ed.), Government $R \& D$ 
Funding and Company Behaviour: Measuring Behavioural Additionality (pp. 205-218). OECD Publishing.

Marzucchi, A., Antonioli, D. and Montresor, S. (2015). Industry-research co-operation within and across regional boundaries. What does innovation policy add? Papers in Regional Science 94(3), 499-524.

Meuleman, M. and De Maeseneire, W. (2012). Do R\&D subsidies affect SMEs' access to external financing? Research Policy, 41(3), 580-591.

Pérez, C. (2016). Designing a Behavioural Additionality Evaluation Methodology for the Knowledge Transfer Partnerships Scheme Employing Case-Based Methods and Theory-Based Evaluation Approaches. Manchester: PREST, The University of Manchester.

Pickering, C. and Byrne, J. (2014). The benefits of publishing systematic quantitative literature reviews for $\mathrm{PhD}$ candidates and other early-career researchers. Higher Education Research \& Development, 33(3), 534-548.

Polt, W. and Psarra, F. (2006). Behavioural Additionality of the EU's $5^{\text {th }}$ Framework Programme. In: OECD (ed.), Government $R \& D$ Funding and Company Behaviour: Measuring Behavioural Additionality (pp. 235-246). OECD Publishing.

Polt, W. and Streicher, G.(2005). Trying to capture additionality in Framework Programme 5 - Main findings. Science and Public Policy, 32(5), 367-373.

Prota L., D’Esposito, M., De Stefano, D., Giordano, G. and Vitale, M. (2013). Modelling Cooperative Behaviours in Innovation Networks: An Empirical Analysis. In: J. Sophrer and L. Freund (eds.). Advances in the human side of service engineering (pp. 369-378). Taylor \& Francis.

Prota, L. and Vitale, M. (2014). A pre-specified blockmodeling to analyze structural dynamics in innovation networks. Studies in Classification, Data Analysis, and Knowledge Organization, 49, 221-229.

Roper, S. and Hewitt-Dundas, N. (2016). The legacy of public subsidies for innovation: input, output and behavioural additionality effects. ERC Research Paper 21.

Shin, T. (2006). Behavioural Additionality of Public R\&D Funding in Korea. In: OECD (Ed.). Government $R \& D$ Funding and Company Behaviour:
Measuring Behavioural Additionality (pp. 167-180). OECD Publishing.

Shipp, S., Wisniewski, L., Wang, A. and Campbell, S. (2006). Behavioural Additionality of the US Advanced Technology Programme. In: OECD (ed.), Government $R \& D$ Funding and Company Behaviour: Measuring Behavioural Additionality (pp. 219-234). OECD Publishing.

Steurs, G., Verbeek, A. and Lykogianni, E. (2009). The behavioural additionality of business $R \& D$ subsidies: theoretical considerations and empirical results for Flanders. In: W. Molle and J. Djarova (eds.), Enhancing the Effectiveness of Innovation: New Roles for Key Players, (pp. 137-147). Edward Elgar.

Steyer, F. (2006). Behavioural Additionality in Austria's Kplus Competence Centre Programme. In: OECD (ed.), Government R\&D Funding and Company Behaviour: Measuring Behavioural Additionality (pp. 75-90). OECD Publishing.

Suzuki, J. and Yumitori, S. (2006). Behavioural Additionality of Public R\&D Funding in Japan. In: OECD (ed.), Government $R \& D$ Funding and Company Behaviour: Measuring Behavioural Additionality (pp. 151-166). OECD Publishing.

Teirlinck, P. and Spithoven, A. (2012). Fostering industry-science cooperation through public funding: Differences between universities and public research centres. Journal of Technology Transfer, 37(5), 676-695.

Neicu, D., Teirlinck, P. and Kelchtermans, S. (2016) Dipping in the policy mix: Do R\&D subsidies foster behavioral additionality effects of R\&D tax credits? Economics of Innovation and New Technology, 25(3), 218-239.

Wanzenboeck, I., Scherngell, T. and Fischer, M. (2013). How do firm characteristics affect behavioural additionalities of public R\&D subsidies? Evidence for the Austrian transport sector, Technovation, 33, 66-77.

Wu, A. (2017). The signal effect of Government R\&D Subsidies in China: Does ownership matter? Technological Forecasting And Social Change, 117, 339-345. 